\title{
Management of premature loss of primary first molar case with simple fixed space maintainer
}

\author{
Sherly Horax \\ Department of Pedodontics \\ Faculty of Dentistry, Hasanuddin University \\ Makassar, Indonesia
}

\begin{abstract}
ABSTRAK
Kehilangan dini gigi molar sulung dapat menyebabkan masalah ruang pada perkembangan lengkung mandibula. Beberapa teknik terapi telah digunakan untuk mengatasi masalah tersebut. Salah satu teknik yang dapat digunakan yaitu terapi dengan space maintainer. Terapi ini dapat menjelaskan tentang kehilangan dini gigi molar sulung dengan menggunakan simple fixed space maintainer yang dikombinasikan dengan molar band dan resin komposit.
\end{abstract}

Kata kunci: Fixed space maintainer, resin komposit, kehilangan dini gigi sulung

\begin{abstract}
Early loss of primary molars may cause a space problem for the arch development. Several techniques have been used to treat this problem. One of the therapies that could be used is space maintainer therapy. This paper will explain the management of premature loss of mandible primary first molar by using a simple fixed space maintainer combined with molar band and resin composite.

Key words: Fixed space maintainer, resin composite, premature loss of the primary teeth

Correspondence: Sherly Horax, Department of Pedodontics, Faculty of Dentistry Hasanuddin University, Jl. Perintis Kemerdekaan m.10, Tamalanrea, Makassar, Indonesia.
\end{abstract}

\section{INTRODUCTION}

Premature loss of primary molar teeth may lead to the problem of arch development because it would cause a mesial drifting of the erupting posterior teeth. Early loss of primary molars and a failure to keep those molar teeth eventually may lead to malocclusion, and for that reason, it would need special attention. ${ }^{1,2}$

Several techniques have been used to cope with these problems and to protect the mesiodistal relationship of the teeth on the central arch. One of the best therapies is space maintainer therapy, because it could maintain those primary molars to be exfoliated naturally. ${ }^{1}$ The goals of the space maintainer treatment are to prevent teeth from drifting and reducing the space available for the permanent teeth, or to maintain some spaces within the arch so that alignment becomes possible. ${ }^{3,4}$

This paper will discuss about management of a case of premature loss on mandible primary first molar by means of space at maintainer which is more simple and comfortable to use, fixed space maintainer combined with molar band and resin composite.

\section{LITERATURE REVIEW}

A space maintainer is appropriate only if it could maintain some space as a guide for the erupting of successor teeth, stabilizing and 
preventing the adjacent teeth migration. Space maintainer doesn't affect the eruption of the permanent teeth and of the oppossing teeth, easy to fabricate, comfortable when it is used, and it is not altered with the chewing and talking function. ${ }^{3,5}$

Indication of the space maintainer is premature loss of primary teeth. Results from space analyzes revealed that there will be enough space of the successor teeth eruption., Meanwhile, the contraindications for this device are reduced or excessive space for the erupting of permanent teeth, crowded teeth, and bad oral hygiene. $^{2,5}$

Space maintainers are classified as fixed space maintainer with band, fixed space maintainer without band, semi-fixed space maintainer, removable space maintainer, and functional space maintainer. ${ }^{5,6}$

The improvement with resin composite material and adhesive system have provided innovations in the techniques used to place space maintainers in the mouth. ${ }^{1}$ Swaine and Wright (cited from Matthewson et al) prepared a fixed space maintainer by using ultra violet light polymerizing resin composite and achieved a rate of failure as much as $30 \%{ }^{4}$ Other researchers used a diffierent bonding system in order to place fixed space maintainers by means of a hybrid resin composite polymerized by visible light cure. ${ }^{5}$ The rate of success was $72 \% .^{6}$

Disadvantages of space maintainer are plaque retention which can cause caries to abutment teeth, tipping and rotation of the abutment teeth, need preparation on the abutment teeth, need of prolonged visiting times, need of laboratory work, soldering area are fragile, and cytotoxic of the solder area. ${ }^{6,7}$

Other reasons of failure of space maintainers are cement dissolving and soldering failure. These situations could potentially make the molar band to submerge into the gingivoalveolar tissues and tend to lead to tipping and rotating in the abutment teeth. ${ }^{1,7,8}$

\section{CASE REPORT}

A seven-year old boy came to the Dental Hospital of Faculty of Dentistry, Hasanuddin University, with the chief complain of the loss mandible primary right first molar because of caries. Intra oral examination revealed that extraction area had healed, the gingiva looked normal, and there were no caries on teeth primary canine and second molar mandible (Fig 1). Immobile and step mesial primary molar relationship should be established.

The procedure of making the appliance are as follows: treatment should been done before space maintainer was dental health education, scalling, and preliminary impression were done to get a cast of the patient's arch. Design of this fixed space maintainer were marked on this model.

The retention was half jackson clasp which was made from $0.6 \mathrm{~mm}$-diameter stainless steel wire. Clasps were placed on the primary right canine and second molar mandible. The clasp on the primary second molar mandible was soldered on the buccal surface of the molar band. The loop placed on the empty space (84) should not touch the mucosa suface as shown on Fig 2.

On the abutment teeth, enamel on facial suface was etched with phosporic acid for 30 seconds, rinsed with water, followed with an air blow to make it dry. Then bonding agent was applied on the enamel-etched surface, and light cured for 30 seconds. The molar band was placed using zinc phosphate cement, and then the mesial area of the primary canine mandible by using flowable composite resin (Fig. 3). 


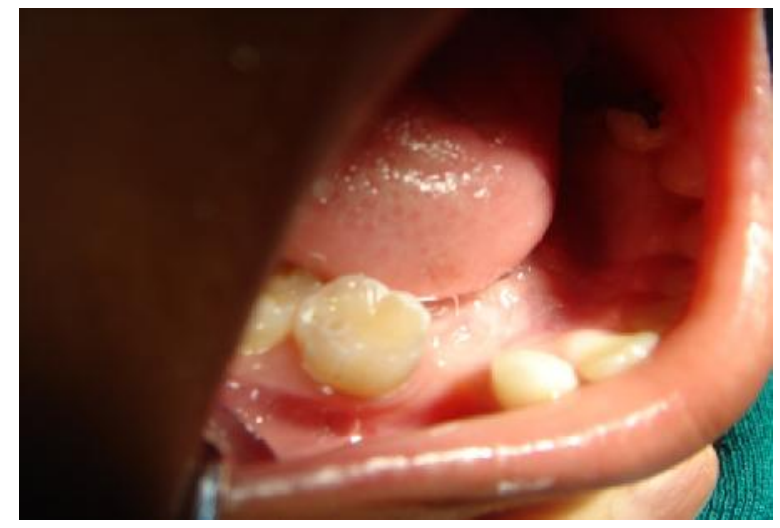

Figure 1. Intra oral condition before space maintainer was placed

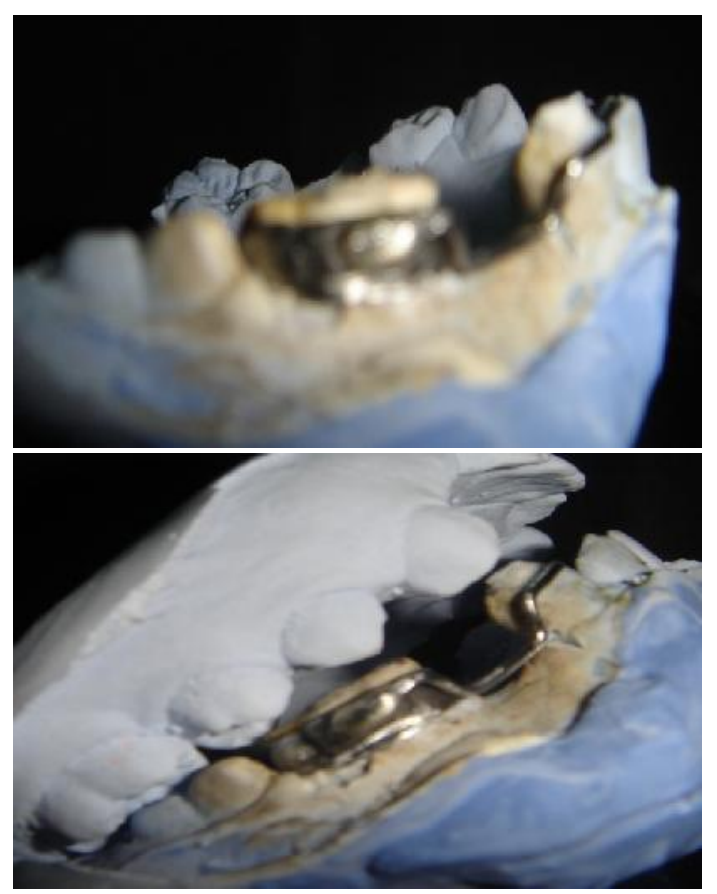

Figure 2. The space maintainer after soldering.

One week later, the patient was asked to come for control. This follow-up was taken to look after the space maintainer, molar band position. Intraoral radiography was takene to predict the erupting time of permanent teeth, and to evaluate some pathologic changes that could occur on abutment teeth, and also the degree of root resorption. the appliance was evaluated every 3 months.

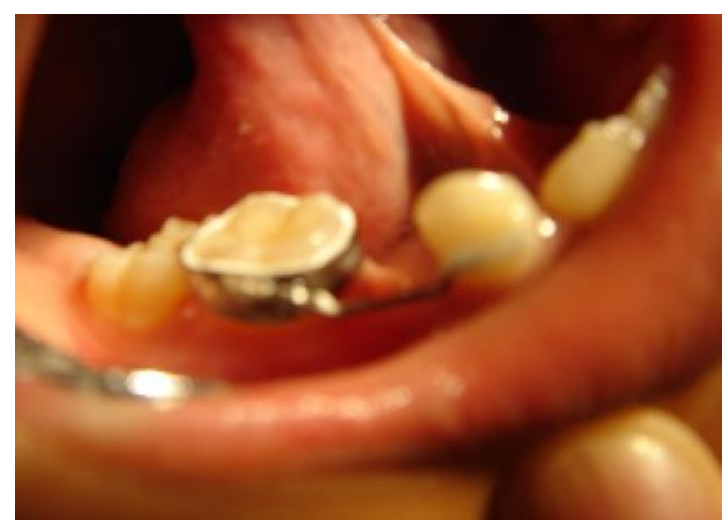

Figure 3. Space maintainer was inserted

\section{DISCUSSION}

The loss of primary teeth before normal physiological exfoliation can cause the collapse of vertical and horizontal occlusal relationships in the primary and permanent dentitions. For this reason, it is important to maintain the spaces caused by the premature loss of primary teeth. ${ }^{1,9,10}$

The advantanges of this modified fixed space maintainer are to have more retentive and stronger, to prevent the tipping movement of the abutment teeth, doesn't affect the eruption of successor teeth, and looks much more esthetic. ${ }^{(1)}$ Fixed space maintainer was made by means of orthodontic wire, so it would be easy to adjust and to avoid the rotation movement of axis wire. $^{6,8}$

One week after the placement of modified fixed space maintainer, it looked stable on its position and no complaint of the patient. Some plaques was found on the molars and the patient was told to improve his oral hygiene.

Three weeks later, no caries or gingival alterations was found on the abutment tooth. However, plaque accumulation existed around the fixed space maintainer. This problem was overcome by providing dental health education to the patient on each control. ${ }^{9-11}$ 


\section{CONCLUSION}

Space resulted from premature loss of primary teeth can be maintained by using an appliance known as space maintainer. Fixed space maintainer with molar band attached with flowable resin composite can be used as a treatment for the premature loss of primary teeth. It has stable strengh and can also provide space for the erupting of successor teeth.

\section{DAFTAR PUSTAKA}

1. Yilmez Y, Kocogullari, Belduz N. Fixed space maintainer combined with open face stainless steel crowns. J Contemp Dent Pract (serial online) 2006 May 1 (cited 2006 Agust 2). Available from: URL: http/www.thejedp. com.

2. Cameron AC, Widmer RP. Handbook of pediatric dentistry $2^{\text {nd }}$ ed. St. Louis: Mosby, Inc; 2003. p.

3. Proffit WR, Field HW. Arckerman JL, Bailey LJ, Tulloch CJF. Contemporary orthodontics, $3^{\text {rd }}$ ed. St. Louis:Mosby: Inc:2000,418-21

4. Mathewson RJ, Primosch RE. Fundanemtals of pediatric denatistry, $3^{\text {rd }}$.ed. Chicago:
Quintessence Publishing Co,Inc; 1995. p.32632.

5. Snawder KD. Handbook of clinical pedodontics. St. Louis: Mosby Co,; 1990.

6. Swaine T, Wright GZ. Direct bonding applied to space maintainer. J Am Dent Assoc 197; 43: 401-5.

7. Hill CJ, Sorenson HW, Mink JR. Space maintainer in child dental program. J Am Dent Assoc 1975; 90: 811-5.

8. Mockers O, Deraze D, Camps J. Citotoxicity orthodontics bands. Brackers and archwires in vitro. Dent Mater 2002:18: 311-7.

9. Finn SB. Clinical pedodontics $4^{\text {th }}$ ed. Philadelpia: WB Saunders Co.; 1973.

10. Kisling E, Hoffding J. Premature loss of primary teeth: Part IV, a Clinical control of sannerud's space maintainer, type I. J Dent Child 1979; 46: 17-21.

11. Simseks S. Clinical evaluation simple fixed space maintained bonded with flow composite resin J Dent Child 2004:71:163-8.

12. Hoffding J, Kisling E. Premature loss of primary teeth: Part II, the specific effect on occlusion and space in the permanent dentition. J Dent Child 1978; 45: 248-7. 